OPEN ACCESS

Edited by:

Jessica Jane Meeuwig,

University of Western Australia,

Australia

Reviewed by:

Abbott Klimley,

UC Davis, United States

Sharon Z. Herzka,

Center for Scientific Research and Higher Education in Ensenada

(CICESE), Mexico

*Correspondence:

Pelayo Salinas-de-León pelayo.salinas@fcdarwin.org.ec

Specialty section:

This article was submitted to Marine Biology,

a section of the journal

Frontiers in Marine Science

Received: 03 November 2020 Accepted: 15 November 2021

Published: 15 December 2021

Citation:

Arnés-Urgellés $C$

Salinas-de-León $P$,

Rastoin-Laplane E, Vaca-Pita L,

Suárez-Moncada J and

Páez-Rosas D (2021) The Effects of

Climatic Variability on the Feeding

Ecology of the Scalloped

Hammerhead Shark (Sphyrna lewini)

in the Tropical Eastern Pacific.

Front. Mar. Sci. 8:625748.

doi: 10.3389/fmars.2021.625748

\section{The Effects of Climatic Variability on the Feeding Ecology of the Scalloped Hammerhead Shark (Sphyrna lewini) in the Tropical Eastern Pacific}

\author{
Camila Arnés-Urgellés ${ }^{1}$, Pelayo Salinas-de-León ${ }^{*}$, Etienne Rastoin-Laplane1, \\ Leandro Vaca-Pita², Jenifer Suárez-Moncada ${ }^{2}$ and Diego Páez-Rosas ${ }^{3}$

\begin{abstract}
${ }^{1}$ Charles Darwin Research Station, Charles Darwin Foundation, Puerto Ayora, Ecuador, ${ }^{2}$ Dirección del Parque Nacional Galápagos, Puerto Ayora, Ecuador, ${ }^{3}$ Galapagos Science Center, Universidad San Francisco de Quito, Isla San Cristobal, Galápagos, Ecuador
\end{abstract}

Climatic variability changes ocean productivity and generates systematic cascading effects in marine food webs. Studying the feeding ecology of top predators, such as sharks, can provide insights into the overall health of marine ecosystems. We conducted a 4-year study to evaluate seasonal and inter-annual trophic variations and their relationship with El Niño Southern Oscillation (ENSO) on the largest aggregation of scalloped hammerhead shark (Sphyrna lewini) in the Tropical Eastern Pacific (TEP). We used $\delta^{13} \mathrm{C}$ and $\delta^{15} \mathrm{~N}$ signatures to gain a better understanding of hammerheads' feeding strategies as well as variations of their isotopic niche. Our results suggest that the hammerhead sharks in the Galapagos Marine Reserve respond to climatic fluctuations, with La Niña event potentially benefiting their trophic needs as the overall marine productivity increased in the region. This work is the first of its kind in the TEP and provides insights on how climate variability influences the feeding ecology of this critically endangered species. It also highlights the need to incorporate climaterelated conservation strategies into the management of this species since ENSO events become more frequent and intense in the face of climate change.

\footnotetext{
Keywords: foraging strategies, $\delta 13 \mathrm{C}$ and $\delta 15 \mathrm{~N}$ signatures, isotopic niche, ENSO (El Nino/Southern Oscillation), Galapagos Islands, Tropical Eastern Pacific
}

\section{INTRODUCTION}

The world's oceans have been under the influence of natural climatic variability for millennia (Walthers et al., 2002; Hoegh-Guldberg and Bruno, 2010), driving marine populations to develop coping adaptations to persist in this environment (Walthers et al., 2002; Sydeman et al., 2015). However, natural climatic variability is now exacerbated by the impacts of human-induced climate change on the world's oceans as it causes natural anomalous events to become more frequent and intense, stretching the capacity of marine species to adapt (Barnett et al., 2005; Pachauri and Reisinger, 2008). Human-induced climate change amplifies natural climatic events, such as El Niño Southern Oscillation (ENSO) cycles and its variations between warm (El Niño) and cold (La Niña) conditions (Cai et al., 2014; Wang et al., 2017), causing large-scale global impacts in marine ecosystems (Hoegh-Guldberg and Bruno, 2010; Doney et al., 2011). 
In the Tropical Eastern Pacific (TEP), El Niño event results in increased sea surface temperature (SST) and stratification of the water column that in turn limits ocean productivity (Cai et al., 2014). Some documented effects of these events include sharp population declines of marine species (Wikelski and Thom, 2000; Edgar et al., 2010; Riofrío-Lazo et al., 2017; Páez-Rosas et al., 2021) and increased incidence of diseases (Lamb et al., 2018; Santana-Piñeros et al., 2020). Furthermore, El Niño event changes the abundance of living resources and shifts their distribution toward better quality habitats (Cheung et al., 2010), and can also negatively affect the survival of higher trophic level species (Barber and Chávez, 1986; Sydeman et al., 2015). For instance, during extreme El Niño events, the biomass of key forage groups, such as small fish and cephalopods, tends to decrease (Griffiths et al., 2010), creating a bottom-up effect that alters the demography of top predators and their feeding behavior (Robinson et al., 2009).

The recurrence of the El Niño event reduces the length and frequency of La Niña events, disrupting cold-water currents and upwellings (Chen and Dool, 1999), having significant impacts on marine predators. This has been previously documented for seabirds and marine mammals of the TEP (Sydeman et al., 2012). Particularly, in the Galapagos Islands, El Niño directly affects the reproductive and foraging success of endemic species, such as penguins, flightless cormorants, and sea lions (Valle et al., 1987; Nims et al., 2008; Páez-Rosas et al., 2012). Considering that climate change is predicted to continue increasing the magnitude and frequency of climatic events such as El Niño (Wang and Fiedler, 2006; Collins et al., 2010; Cai et al., 2014), studying the impact on the structure of marine food web and the feeding ecology of their top predators is thus key to understand ecosystem function and to develop conservation strategies.

Top predatory sharks sit at the top of marine food webs, regulating the size and dynamics of communities below them (Myers et al., 2007) and maintaining marine ecosystems balanced (Dulvy et al., 2008; Heupel et al., 2014). However, the fast depletion of sharks, mainly due to overfishing (Casini et al., 2009; Pacoureau et al., 2021), has produced negative cascading effects on marine food webs that affect the functioning of the ecosystem and its biodiversity (Heithaus et al., 2008; Baum and Worm, 2009; Estes et al., 2011). The synergistic effects of anthropogenic activities and natural climatic variability can result in a lack of top-down control exerted by top predators, ultimately degrading global marine ecosystems (Stevens et al., 2000; Dulvy et al., 2008; Ferretti et al., 2010). Presently, only few well-protected or very remote locations still harbor relative pristine food webs where sharks are abundant (Ferretti et al., 2018). The Galapagos Marine Reserve (GMR) has some of the largest global shark aggregations (Salinas-de-León et al., 2016; Acuña-Marrero et al., 2018) and is located at the epicenter of ENSO cycles, being thus an ideal natural laboratory to study the impact of climatic variability on marine ecosystems (Edgar et al., 2010; Salinas-de-León et al., 2020).

Previous studies on the feeding ecology of top predators at the GMR have been conducted mainly on seabirds and marine mammals (Awkerman et al., 2007; Paez-Rosas et al., 2017; Jimenez-Uzcategui et al., 2019; Schwarz et al., 2021), with some studies focusing on teleost fish (Baque-Menoscal et al., 2012; Páez-Rosas et al., 2020a) and sharks (Páez-Rosas et al., 2018a; Salinas-de-León et al., 2019). These studies have used a combination of gut content and/or stable isotope analysis (SIA), with most of them focusing on single-year sampling, with just two published studies that included multi-year sampling: Whitehead et al. (1989) studied the feeding success of sperm whales (Physeter macrocephalus) based on scat analysis before and during the 1987 El Niño year, documenting a similar diet between both years, but revealing an apparent lower feeding success associated with increase SST during the El Niño event. More recently, Páez-Rosas et al. (2020b) revealed that Galapagos sea lions (Zalophus wollebaeki) exhibited trophic flexibility during the $2015 \mathrm{El}$ Niño event by reducing the foraging niche and increasing the consumption of prey from greater depths. In this regard, SIA offers a methodological approach that allows to infer food source in marine predators, based on the principle that the isotopic composition of a prey item is retained in the predator's tissues (Hobson et al., 1995). This technique is a powerful tool to validate shark movements, habitat preferences, and ecological niche size over specific periods (Carlisle et al., 2012; Tamburin et al., 2019; Trueman and Glew, 2019).

The northern Galápagos islands of Darwin and Wolf are home to one of the last large aggregations of the critically endangered scalloped hammerhead shark (Sphyrna lewini) (Salinas-de-León et al., 2016), and these large groups are mostly composed of adult females (Klimley, 1987), some seemingly pregnant during the first months of the year (Ketchum et al., 2014). Scalloped hammerhead sharks are known to migrate between the oceanic islands of the TEP (Bessudo et al., 2011; Ketchum et al., 2014; Nalesso et al., 2019), and females have been speculated to migrate to coastal waters to give birth to their young after March (Salinas-de-León et al., 2017), when the presence of newborns has been documented in nursery areas within continental coastlines (Robles et al., 2015; Zanella et al., 2019). Despite scalloped hammerhead sharks being enlisted as Critically Endangered in the IUCN red list of endangered species due to the continuous global population declines, including across marine protected areas of the TEP (White et al., 2015; Peñaherrera-Palma et al., 2018), we still have a limited understanding about their basic life history, including their trophic ecology. In this study, we determine the $\delta^{13} \mathrm{C}$ and $\delta^{15} \mathrm{~N}$ signatures of the critically endangered scalloped hammerhead shark (Sphyrna lewini) to assess seasonal and inter-annual trophic variability during a 4year period, in which ENSO cycles occurred, with the purpose of understand how these conditions affect the feeding ecology of this species.

\section{MATERIALS AND METHODS}

\section{Ethics Statement}

This investigation was conducted under Galapagos National Park Directorate (GNPD) research permits PC-28-16, PC-2717, PC-46-18, and PC-53-19 issued to Dr. Pelayo Salinas de León of the Charles Darwin Foundation (CDF), and research permits PC-24-17, PC-69-18, and PC-86-19 issued to 
Dr. Diego Páez-Rosas from the University San Francisco de Quito (USFQ). Biopsy samples were collected in situ from free-swimming specimens following animal ethics protocols by the GNPD and CDF.

\section{Study Site}

The Galapagos Islands lie at the epicenter of the thermal anomalies that occur during ENSO cycles (Wellington et al., 2001). The oceanographic setting in this region is unique, and it is responsible for the colonization and evolution of various species whose ecological characteristics are not considered otherwise typical for a low-latitude ecosystem (Wikelski and Thom, 2000; Edgar et al., 2004). During El Niño, cold upwellings disappear resulting in a deeper thermocline and the warming of surface waters and lowering of productivity, which can last for many months up to a year (Victor et al., 2001; Wellington et al., 2001). The opposite effect occurs when La Niña brings cool Peruvian waters creating cold-water refuges and enhancing ocean productivity (Chavez et al., 2003). This recurrent climate variation serves as an opportunity for Galapagos species to adapt to these transitions, but it makes them prone to rapid population declines and risk of extinction when facing extreme ENSO cycles, such as the 1982-1983 and 1997-1998 El Niño events (Edgar et al., 2010).

Darwin and Wolf islands are located at the far northern region of the GMR (Figure 1), where the warm Panama Current flows in a south-western direction causing higher temperatures around these islands than in the rest of the archipelago (Banks et al., 2009). As a result, there are two defined seasons at Darwin and Wolf: the warm season that occurs from January to June and the cool season from July to December with an overall average temperature of $24^{\circ} \mathrm{C}$ (Acuña-Marrero et al., 2014). Moreover, these remote islands with a surface area of less than $2 \mathrm{~km}^{2}$ each and located approximately $36 \mathrm{~km}$ apart (Harpp and Geist, 2002) are world-renowned hotspots for harboring large aggregations of marine megafauna, such as the critically endangered scalloped hammerhead (Ruiz et al., 2016; Salinas-de-León et al., 2016).

\section{Sampling}

Sample collection took place from 2016 to 2019 during the cool (July-December) season, and in 2019 during the warm (JanuaryJune) and cool seasons. A total of 139 tissue biopsies were collected from adult ( $>2.25 \mathrm{~m}$ TL) female scalloped hammerhead sharks. Lengths were estimated visually by experienced divers in $25 \mathrm{~cm}$ bins (i.e., 200-225-250-275) and based on previous stereovideo measurements (Klimley and Brown, 1983; Salinas-de-León et al., 2016). We obtained skin tissue from free-swimming scalloped hammerhead sharks by freediving among the large aggregations that occur at Darwin Island. We used a modified Hawaiian sling with a biopsy dart (Pneu-dart, Inc., United States) at the top end to collect $1 \mathrm{~cm}^{3}$ of tissue. We targeted the base of the dorsal fin by releasing the Hawaiian sling from a perpendicular angle to the hammerhead at an approximate distance of $1 \mathrm{~m}$. The skin samples were removed from the tip of

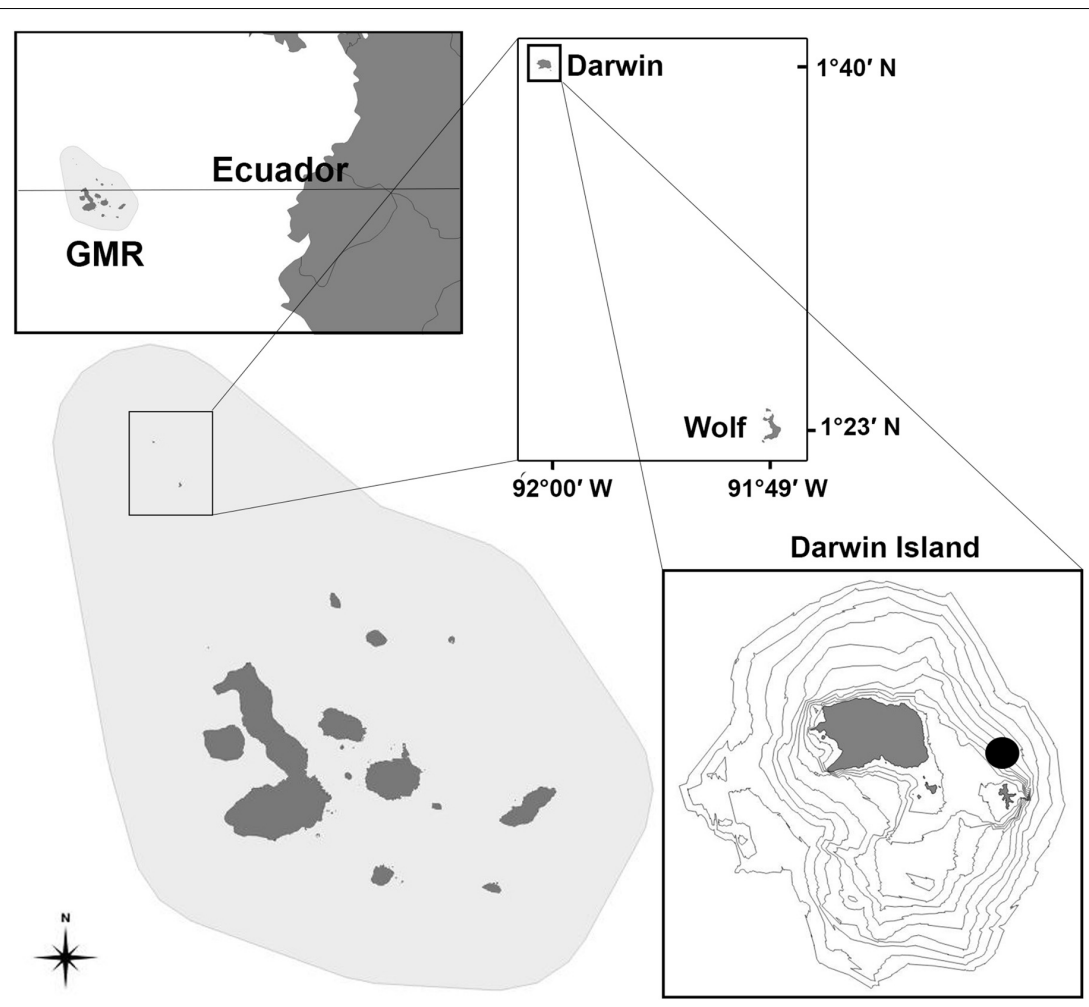

FIGURE 1 | The galapagos marine reserve, with the location of Darwin Island, where tissue samples were collected to study the trophic ecology of aggregating scalloped hammerhead sharks (Sphyrna lewini) between 2016 and 2019. 
the biopsy dart, placed in Eppendorf tubes with 70\% Ethanol, and stored at $-20^{\circ} \mathrm{C}$.

\section{Stable Isotope Analysis}

Tissue samples were rinsed with deionized water to eliminate residues that could alter their isotopic signature and placed in glass vials previously treated for $24 \mathrm{~h}$ with a chromic acid mixture prepared from sulfuric acid and potassium dichromate. Then, sampled were dried in a desiccator at $80^{\circ} \mathrm{C}$ for $12 \mathrm{~h}$ to remove all moisture. A lipid-extracted protocol was applied via three sequential $24 \mathrm{~h}$ soaks in a 2:1 chloroform: methanol solvent solution, then rinsed with deionized water, and dried again. This process was applied because lipids are rich in ${ }^{12} \mathrm{C}$, which, in sufficiently large quantities, could negatively skew the ${ }^{13} \mathrm{C}$ isotopic signature (Post et al., 2007). All samples were homogenized with an agate mortar to obtain a very fine powder, of which $1 \mathrm{mg}$ was weighed by means of an analytical microbalance with a precision of $0.001 \mathrm{mg}$ and transferred into a tin capsule.

$\delta^{13} \mathrm{C}$ and $\delta^{15} \mathrm{~N}$ signatures were determined by a PDZ Europa 20-20 continuous-flow isotope-ratio mass spectrometer (Sercon Ltd., Cheshire, United Kingdom) at the Stable Isotope Facility of the University of California at Davis (Davis, CA, United States). The results were expressed in parts per thousand $(\% 0)$ using the equation: $\delta_{\mathrm{X}}=\left[\left(\mathrm{R}_{\text {sample }} / \mathrm{R}_{\text {standard }}\right)-1\right] * 1,000$, where $\delta_{\mathrm{X}}$ is the heavy isotope and $\mathrm{R}_{\text {sample }}$ and $\mathrm{R}_{\text {standard }}$ are the ${ }^{13} \mathrm{C} /{ }^{12} \mathrm{C}$ or ${ }^{15} \mathrm{~N} /{ }^{14} \mathrm{~N}$ ratios of the sample and the standard, respectively. The internationally accepted standard for carbon is Vienna-Pee Dee Belemnite limestone (V-PDB) and for nitrogen is atmospheric $\mathrm{N}_{2}$. Within-run analytical precision of $\pm 0.2 \% 0$ for both $\delta^{13} \mathrm{C}$ and $\delta^{15} \mathrm{~N}$ values was calculated by using two proteinaceous internal reference materials. We also measured the weight percent carbon and nitrogen concentration $(\mathrm{C} / \mathrm{N})$ of each sample, which was an indicator of lipid content (Logan et al., 2008).

\section{Statistical Analysis}

Data were tested for normality and homoscedasticity using the Shapiro-Wilk and Levene test, respectively. The statistical significance of differences in $\delta^{13} \mathrm{C}$ and $\delta^{15} \mathrm{~N}$ values was determined using parametric or non-parametric tests, along posteriori multiple comparison tests. Significance is reported in terms of $p<0.05$. All statistical analyses were performed in $\mathrm{R}$ language. The Bayesian standard ellipse areas (SEA) were used to estimate isotopic niche width and overlap among hammerhead shark samples collected in different years using the package SIBER (Stable Isotope Bayesian Ellipses in statistical software R) (Jackson et al., 2011). This Bayesian method provides a measure of the isotopic niche area at the population level, expressed as the SEA in units of area $\left(\%^{2}\right)$ and contains $95 \%$ of the data for each group. We used Monte Carlo simulations to correct the bivariate ellipses $\left(\delta^{13} \mathrm{C}\right.$ and $\left.\delta^{15} \mathrm{~N}\right)$ surrounding the data points in the $95 \%$ confidence interval for the distributions of both stable isotopes (Jackson et al., 2011). These corrected standard ellipse areas (SEAc) represent the isotopic niche width and the overlap parameters. The magnitude of the isotopic overlap $\left(\% 0^{2}\right)$ among years was estimated using the estimations of the ellipses via maximum-likelihood methods (Jackson et al., 2011).

The ENSO effects on the isotopic values were examined by correlation analysis between the Southern Oscillation Index $($ SOI $1+2)$ and the isotopic values of $\delta^{13} \mathrm{C}$ and $\delta^{15} \mathrm{~N}$ for individual sharks on each year. These correlations were assessed by Pearson correlation using $\mathrm{R}$ program. The SOI is the average of the monthly sea surface temperature (SST) anomalies in time series data relative to historical climatological values (i.e., 1971-2000) in regions $1+2$ (data obtained from www.ncdc.noaa.gov/teleconnections/enso/indicators/soi). Although there is not much information published about the tissue turnover rate of shark skin, it has been suggested to be between that of muscle ( $>1$ year) and liver (around 6 months) (MacNeil et al., 2005; Carlisle et al., 2012; Kim and Koch, 2012; Li et al., 2016). Therefore, we have used the average of 6 months of SOI $1+2$ values in each year for this analysis.

The effects of other environmental variables were also analyzed, such as SST and chlorophyll-a concentration $\left(\mathrm{mg}^{*} \mathrm{~m}^{3}\right)$ were examined in the region. The count data series were from 2016 to 2019 around Darwin and Wolf islands. SST and chlorophyll-a values were obtained from satellite images taken at a resolution of $4.4 \mathrm{~km}$ [Dataset: SST, POES AVHRR, GAC, Global, Day and Night (Monthly Composite)] and are available on the ERDDAP data server from the NOAA website ${ }^{1}$. Pearson's rank correlation coefficient was used to analyze the relationship between $\delta^{13} \mathrm{C}$ and $\delta^{15} \mathrm{~N}$ signatures and the environmental variables.

\section{RESULTS}

$\mathrm{C} / \mathrm{N}$ ratios in the tissue of hammerhead sharks ranged from 2.7 to 3.6: within the established range for a predator's diet (Logan et al., 2008). Mean estimated $\delta^{13} \mathrm{C}$ and $\delta^{15} \mathrm{~N}$ values during the warm season were $-13.41 \pm 0.60 \%$ and $12.29 \pm 0.56 \%$, respectively; and during cold season, they were $-13.56 \pm 0.58 \%$ and $12.16 \pm 0.68 \%$, respectively (Table 1 ). There were no differences among $\delta^{13} \mathrm{C}$ (Mann-Whitney $U$-test, $p=0.261$ ) and $\delta^{15} \mathrm{~N}$ values (Mann-Whitney $U$-test, $p=0.238$ ) for the year

$\overline{{ }^{1} \text { http://coastwatch.pfeg.noaa.gov/erddap }}$

TABLE 1 | Summary of tissue samples collected for isotopic analysis on scalloped hammerhead sharks (Sphyrna lewini) at Darwin Island, Galapagos Marine Reserve.

\begin{tabular}{lcccc}
\hline Season & $\boldsymbol{n}$ & $\boldsymbol{\delta}^{\mathbf{1 3}} \mathbf{C}(\%)$ & $\boldsymbol{\delta}^{\mathbf{1 5}} \mathbf{N}(\%)$ & $\mathbf{C} / \mathbf{N}$ \\
\hline August 2016 & 30 & $-13.39 \pm 0.60$ & $12.32 \pm 0.49$ & $2.77 \pm 0.16$ \\
& & $-(12.38-14.53)$ & $(11.39-13.58)$ & $(2.62-3.23)$ \\
December & \multirow{2}{*}{30} & $-13.48 \pm 0.55$ & $12.20 \pm 0.41$ & $2.74 \pm 0.14$ \\
2016 & & $-(12.57-14.49)$ & $(11.69-13.19)$ & $(2.64-3.42)$ \\
August 2017 & \multirow{2}{*}{30} & $-13.49 \pm 0.48$ & $12.32 \pm 0.60$ & $2.78 \pm 0.13$ \\
& & $-(12.70-14.52)$ & $(11.23-13.72)$ & $(2.62-3.23)$ \\
January 2018 & \multirow{2}{*}{8} & $-13.02 \pm 0.45$ & $12.59 \pm 0.14$ & $2.85 \pm 0.06$ \\
& \multirow{2}{*}{7} & $-(12.24-13.49)$ & $(12.40-12.80)$ & $(2.79-2.94)$ \\
February 2019 & 7 & $-13.35 \pm 0.66$ & $12.38 \pm 0.73$ & $2.85 \pm 0.15$ \\
& \multirow{2}{*}{34} & $-13.75 \pm 0.56$ & $12.01 \pm 0.87$ & $3.10 \pm 0.25$ \\
October 2019 & \multirow{2}{*}{} & $-(12.81-14.93$ & $(10.40-15.05)$ & $(2.77-3.64)$
\end{tabular}


2019 seasonal comparison (Table 1). We detected significant inter-annual variations in $\delta^{13} \mathrm{C}$ and $\delta^{15} \mathrm{~N}$ values (Kruskal-Wallis test, $p=0.028$ and 0.022 , respectively), with values for 2018 differing from those of 2019 (multiple comparisons of median ranks, $p<0.05$ ) (Table 2). The comparison of $\delta^{13} \mathrm{C}$ and $\delta^{15} \mathrm{~N}$ values between years showed that hammerhead sharks in 2018 (mean -13.02 and $12.59 \%$, respectively) maintained an inshore strategy and higher trophic level than in other years (Table $\mathbf{1}$ and Figure 2).

Corrected standard ellipse area (SEAc) showed that hammerhead sharks in warm and cold seasons could be exploiting similar habitats (Figure 3). Mean SEA for each year and proportion of SEAc among the 4 years are shown in Table 3. The Bayesian ellipse of 2018 (SEAc $=0.29 \%$, 95\% credibility interval of $0.05-0.53 \% 0)$ and 2019 (SEAc $=1.71 \%, 95 \%$ credibility interval of 1.09-3.33\% ) had a low overlap (Figure 4), confirming different resource use patterns for these years. In contrast, the Bayesian ellipse of 2016 (SEAc $=0.83 \%$, 95\% credibility interval of $0.42-1.24 \%$ ) and 2017 (SEAc $=0.91 \%$, 95\% credibility interval of $0.46-1.36 \% 0$ ) are overlapped in large part with the ellipse of 2019. The overlap area (0.12) of the Bayesian ellipses from 2018 and 2019 represented the 38.1\% of the ellipse surface of the former and the $4.5 \%$ of the ellipse surface of the latter. Conversely, a significant isotopic overlap was observed between 2016 and 2017 (0.61), accompanied by a high isotopic overlap between 2019 vs. 2016 and 2017 (0.46 and 0.48 , respectively), showing a similar use of resources in these years. However, the Bayesian ellipse of 2019 was larger at $\delta^{13} \mathrm{C}$ and encompassed most of the Bayesian ellipses of other years (Figure 5).

The relationship between the $\delta^{13} \mathrm{C}$ and $\delta^{15} \mathrm{~N}$ values of hammerhead sharks in each year with the SOI $1+2$ is shown in Figure 4. Overall, there was an increase in the mean $\delta^{13} \mathrm{C}$ and $\delta^{15} \mathrm{~N}$ that coincided with the La Niña event of 2018. During cold year, the $\delta^{13} \mathrm{C}$ values increased $0.52 \%$, while $\delta^{15} \mathrm{~N}$ values increased $0.37 \%$ in relation to the average of other years. A negative but no significant correlation was found between the ENSO and the $\delta^{13} \mathrm{C}$ and $\delta^{15} \mathrm{~N}$ values of hammerhead sharks (Pearson's correlation, $\delta^{13} \mathrm{C}: r=-0.74$, $p=0.259$ and $\left.\delta^{15} \mathrm{~N}: r=-0.78, p=0.241\right)$. There were no significant relationships between the environmental variables and $\delta^{13} \mathrm{C}$ and $\delta^{15} \mathrm{~N}$ signatures in any years (Table 4 ). However, both isotopic signatures showed a slight positive trend with SST and chlorophyll-a values in 2018 year.

TABLE 2 | Differences in $\delta^{13} \mathrm{C}$ (above diagonal) and $\delta^{15} \mathrm{~N}$ (below diagonal) values in females scalloped hammerhead sharks in the GMR.

\begin{tabular}{lcccc}
\hline & $\mathbf{2 0 1 6}$ & $\mathbf{2 0 1 7}$ & $\mathbf{2 0 1 8}$ & $\mathbf{2 0 1 9}$ \\
\hline$\delta^{\mathbf{1 3} C(\%)}$ & & & & \\
2016 & $X$ & 0.936 & $\mathbf{0 . 0 3 3}$ & $\mathbf{0 . 0 4 1}$ \\
2017 & 1 & $X$ & $\mathbf{0 . 0 2 9}$ & $\mathbf{0 . 0 4 9}$ \\
2018 & 0.118 & 0.409 & $X$ & $\mathbf{0 . 0 0 1}$ \\
2019 & 1 & 0.286 & $\mathbf{0 . 0 1 1}$ & $X$ \\
\hline
\end{tabular}

Significant variations (Kruskal-Wallis multiple comparisons test, $p<0.05)$ are shown in bold.

\section{DISCUSSION}

This is the first study of its kind for a top predatory shark, providing insights on how their feeding ecology varies under the influence of climatic variability in the TEP. Hammerheads showed a response on their feeding behavior to climatic fluctuations, with La Niña potentially benefiting their foraging activities as a result of the increased productivity in the region (Barber et al., 1996; Behrenfeld et al., 2006). Although our study did not include the peak (August-February) of the 20152016 El Niño event, our data suggest that during warmer years, hammerheads' nutritional efficiency may diminish across the region and hammerhead trophic niche may widen as they possibly adopt a more generalist feeding behavior, which might involve an increase on the use of offshore environments as feeding grounds. However, our results need to be interpreted with caution since with the present dataset, it is not possible to clearly distinguish whether these interannual changes may reflect changes in prey availability, foraging strategy, location, or a combination of the above.

\section{El Niño Southern Oscillation Effects}

NOAA reports indicate that 2018 was a strong La Niña year that brought enriched cold-water currents from southern Peru to the equatorial zone, causing SST to remain $1^{\circ} \mathrm{C}$ anomaly cooler than average (Páez-Rosas et al., 2018b). The warm to cold transition that occurs during ENSO cycles greatly benefits the TEP providing a negative feedback that pushes warm waters back to the western Pacific allowing the entire system to recharge its primary productivity by enhancing upwellings (Wang and Fiedler, 2006). With these productive waters, inshore prey with high $\delta^{13} \mathrm{C}$ valued become more abundant, such as anchovies and mackerels that have been found to be dominant in pelagic sharks' stomach contents during cool-water periods (Preti et al., 2004; Rosa and Seibel, 2008). Behrenfeld et al. (2001) demonstrated that during the 1999-2000 La Niña year, surface chlorophyll concentration significantly increased in the Pacific, and this was reflected by a boost in phytoplankton biomass in the TEP.

The 1999-2000 La Niña year also featured localized upwellings producing coastal krill aggregations off Monterey Bay, California attracting large concentrations of cetaceans around the area, that benefitted of these prey distribution shifts (Benson et al., 2002). Similarly, in Peru, main pelagic resources like anchovies (Engraulis ringens) have being recorded during La Niña cold conditions as they become highly abundant and show a more localized distribution aggregating in coastal areas (Niquen and Bouchon, 2004). This has caused the pelagic fisheries off southern Peru, during La Niña years, to have higher catch per unit effort rates of blue sharks (Prionace glauca), which in turn has been linked to an increase in the abundance of prey in areas where blue sharks feed (Adams et al., 2016). Further research is required to elucidate how the trophic niche of these predators interacts with shark fisheries around the GMR and across the TEP (Martínez-Ortiz et al., 2015).

Our results suggest that the 2018 La Niña might have likely boosted the availability of prey items, which in turn might have resulted in changes on the foraging strategy and trophic 


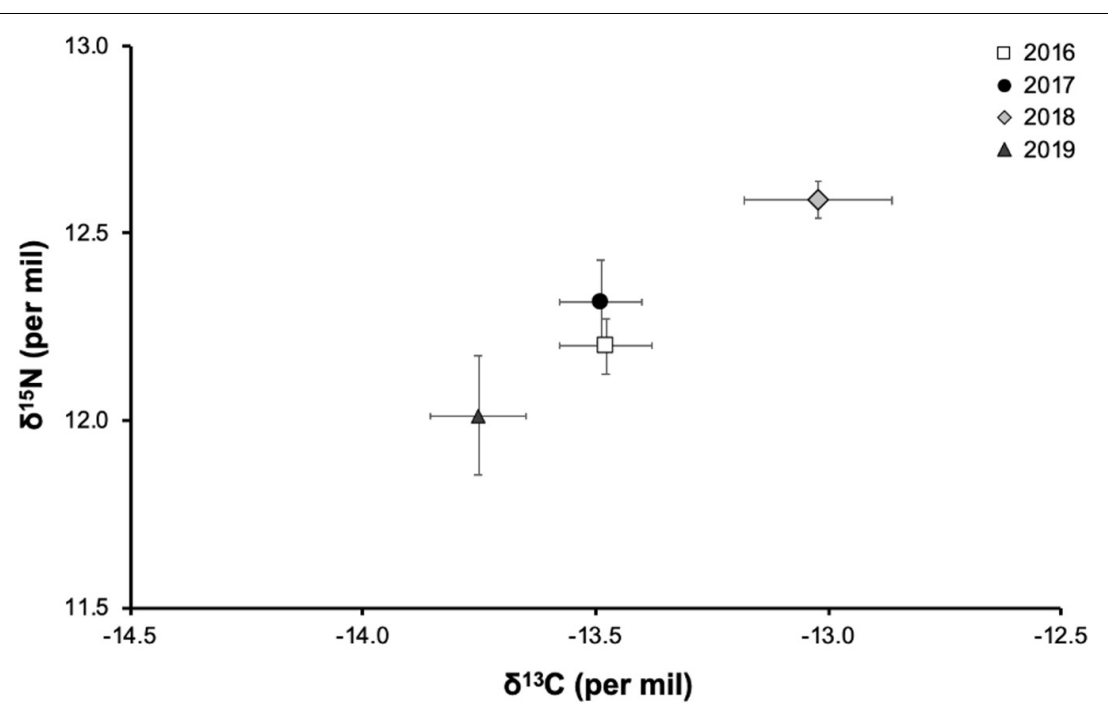

FIGURE 2 | Values of $\delta^{13} \mathrm{C}$ and $\delta^{15} \mathrm{~N}$ (mean \pm SE in \%) in adult female hammerhead sharks over four consecutive years (2016-2019) at Darwin Island, Galapagos Marine Reserve.



FIGURE 3 | Isotopic niche area $\left(\delta^{13} \mathrm{C}\right.$ and $\delta^{15} \mathrm{~N}$ values) and degree of trophic niche overlap for adult female hammerhead sharks during the 2019 warm (January-June) and cold (July-December) seasons at Darwin Island, GMR. The ellipse areas show the degree of trophic niche overlap among seasons.

niche size of hammerheads, as well as enriched in the $\delta^{13} \mathrm{C}$ and $\delta^{15} \mathrm{~N}$. For example, diet studies in the thresher shark (Alopias vulpinus) off the Pacific coast of North America revealed

TABLE 3 | Basic standard ellipse area (SEA) and standard ellipse area correction (SEAc) values as an approximation of the trophic niche breadth (TNB).

\begin{tabular}{lccc}
\hline Years & SEA & SEAc & TNB \\
\hline 2016 & 0.813 & 0.827 & 2.993 \\
2017 & 0.850 & 0.912 & 3.544 \\
2018 & 0.196 & 0.288 & 1.269 \\
2019 & 1.663 & 1.663 & 6.822 \\
\hline
\end{tabular}

The values were obtained using stable isotope Bayesian ellipses of samples from skim tissues of females scalloped hammerhead sharks in the Galapagos Marine Reserve. that during cool water La Niña periods sharks displayed a narrower trophic spectrum and the prevalence of market squid (Loligo opalescens) in their diet increased significantly (Preti et al., 2004). It could also be the case that hammerheads benefit from the increase of prey items such as demersal fish and jumbo squid (Dosidicus gigas), species that are highly consumed by the scalloped hammerhead in other locations across the TEP (Galván-Magaña et al., 2013; Torres-Rojas et al., 2015). Other potential explanation for the changes in isotopic results observe in this study might be the fluctuations in isotopic composition of the prey due to shifts in the marine productivity and isotopic baseline, and further research is required to elucidate this.

During 2015 and early 2016, SST values increased in the region due to the presence of a strong El Niño (Penalba and Rivera, 2016; Lamb et al., 2018) resulting in lower $\delta^{13} \mathrm{C}$ and $\delta^{15} \mathrm{~N}$ 

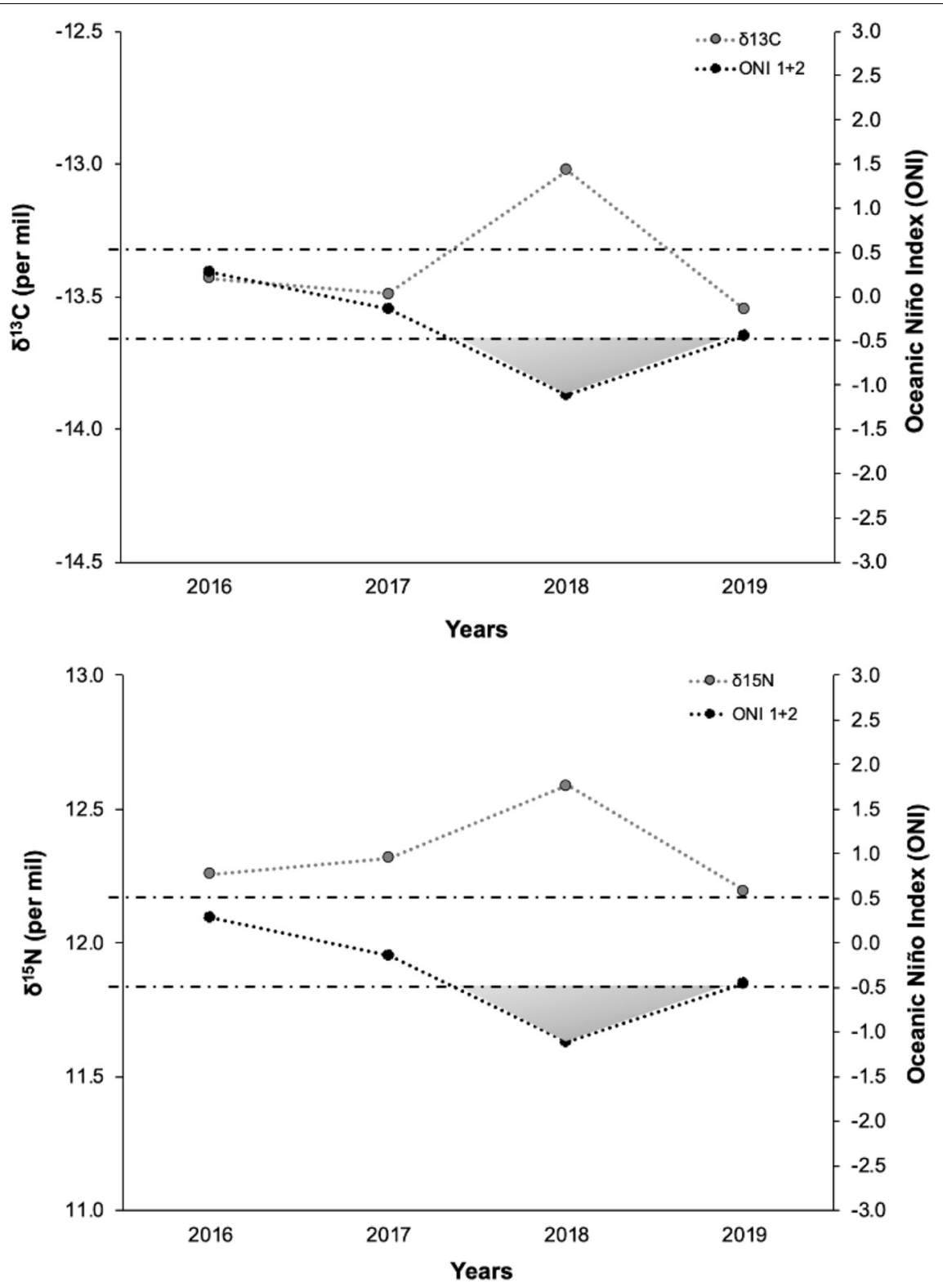

FIGURE 4 | Mean $\left( \pm\right.$ SD) $\delta^{13} \mathrm{C}$ and $\delta^{15} \mathrm{~N}$ values of adult female hammerhead sharks in relation to the Oceanic Niño Index $1+2$. The values of the ONI $1+2$ plotted for each year correspond to the mean of the 6 months for each season. The ONI $1+2$ indicates the intensity of El Niño (positive values) and La Niña (negative values) events that can be considered weak (with a 0.5-0.9 SST anomaly), moderate (1.0-1.4), or strong ( $\geq 1.5)$.

signatures. These values might have decreased due to the lack of $\delta^{15} \mathrm{~N}$ rich demersal prey, which in turn might have caused foraging strategies to shift toward consuming available epipelagic prey, lower in $\delta^{15} \mathrm{~N}$ content (Torres-Rojas et al., 2015). Although El Niño years result in a decreased in ocean productivity in the eastern Pacific (Barber et al., 1996), these have also been linked to increases in pelagic diversity in this region (Niquen and Bouchon, 2004). Hence, the diet of some pelagic sharks becomes more varied during El Niño years of the pacific coast of North America (Preti et al., 2004, 2012). Therefore, in less favorable environments, top predators have shown to become opportunistic and diversify their diet (Preti et al., 2004), foraging sub-optimally as nutrient depleted prey becomes more available (Preti et al., 2012; Munroe et al., 2014).

Alterations in climatic events and rising SST can also create heat waves that affect the distribution and abundance of species (Wernberg et al., 2013). The effects can be direct through physiological stress and indirect through altered predator-prey interactions (Rosa and Seibel, 2008; Wernberg et al., 2013). Both direct and indirect heat waves effects have been previously documented on sharks (Myers et al., 2007; Pistevos et al., 2015). It is predicted that by the end of the twenty-first century, the TEP will become $2-3^{\circ} \mathrm{C}$ warmer due to the weakening of tropical circulations (Pachauri and Reisinger, 2008), and as a result, 


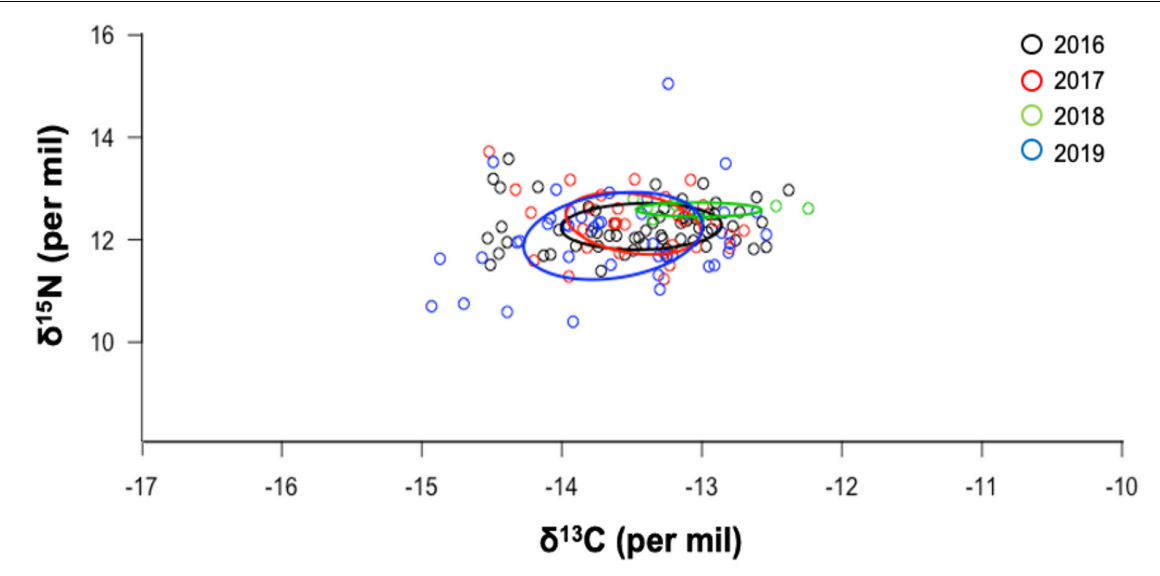

FIGURE 5 | Isotopic niche area $\left(\delta^{13} \mathrm{C}\right.$ and $\delta^{15} \mathrm{~N}$ values) of adult female hammerhead sharks during four consecutive years (2016-2019) sampled at Darwin Island, GMR. The ellipse areas show the degree of trophic niche overlap among years.

community shifts, and trophic structures alterations will follow (Wernberg et al., 2013) along with an increment on the incidence of diseases (Santana-Piñeros et al., 2020). Although further evidence is required to fully understand the impact of climatic variability, our results suggest that the high foraging adaptability and mobility of scalloped hammerhead sharks might confer this species some level of resilience to these extreme events.

\section{Ecosystem Changes and the Role of Sharks}

Generally, scalloped hammerheads feed on epipelagic and mesopelagic species (Klimley, 1987; Torres-Rojas et al., 2006), presenting high $\delta^{15} \mathrm{~N}$ values as they regularly occupy high trophic positions (Richert et al., 2015; Shiffman et al., 2019). This trait makes them vulnerable to malnutrition or starvation when preferred prey is scarce and satisfying their metabolic requirements becomes a challenge (Griffiths et al., 2010; Rojas et al., 2014; Pistevos et al., 2015). Previous studies have demonstrated that elevated temperatures increase sharks' energetic demands as well as reduce their metabolic efficiency (Pistevos et al., 2015).

Hammerheads are highly sensitive to changes in temperatures but have a strong capacity for adaptive plasticity over time (Sydeman et al., 2015). Our analyses support this statement by demonstrating how in the years 2016 and 2019 hammerhead

TABLE 4 | Pearson's rank correlation coefficient results.

\begin{tabular}{lcc}
\hline Isotopic signature & Variables & Pearson rank correlation coefficient result \\
\hline$\delta^{13} \mathrm{C}$ & SST & $r=0.30$ \\
& Chl a & $r=0.40$ \\
$\delta^{15} \mathrm{~N}$ & SST & $r=0.38$ \\
& Chl a & $r=0.25$ \\
\hline
\end{tabular}

Relationships between $\delta^{13} \mathrm{C}$ and $\delta^{15} \mathrm{~N}$ signatures and environmental variables from 2016 to 2019 for sea surface temperature (SST) and Chlorophyll-a.

No relationship was significant at $p=0.05$. niche becomes wider, likely adopting a more generalist feeding approach in the face of warmer temperatures in their surrounding waters. Examples of these diet behavioral shifts have been observed in other large pelagic species; thresher shark (Alopias vulpinus), bull shark (Carcharhinus leucas), and skipjack tuna (Katsuwonus pelamis) as their population abundance varies and their distribution changes to inshore habitats in the face of extreme climatic events (Lehodey et al., 1997; Preti et al., 2004; Matich and Heithaus, 2012).

Hammerheads sharks are also very selective of their habitat and generally preferred warm waters (between 23 and $26^{\circ} \mathrm{C}$ ) above the thermocline to rest and regulate their metabolism before beginning hunting activities (Hoffmayer et al., 2013; Ketchum et al., 2014). Numerous feeding studies have documented the diel vertical movements that hammerhead sharks undertake into deep waters $(>200 \mathrm{~m})$ to feed on demersal fish and cephalopods (Klimley, 1993). Large adult female hammerheads are known to perform up to 70 daily deep, night foraging dives (Hoffmayer et al., 2013; Ketchum et al., 2014). Ocean warming and acidification may increase sharks' metabolism and oxygen demands leading to possibly circulatory stress (Rosa and Seibel, 2008; Pistevos et al., 2015). However, these species has demonstrated to be highly adaptive, moving from the surface of the ocean to near the bottom, even diving into anoxic waters, and likely finding prey in both environments (Jorgensen et al., 2009). Our results provide additional evidence on the foraging adaptability of this species during fluctuating climatic events.

\section{Mobility and Management Implications}

Movements and habitat use of scalloped hammerheads show a strong philopatric behavior around Darwin and Wolf islands (Ketchum et al., 2014). During the warm season (JanuaryJune), however, the water column structure around Darwin and Wolf islands becomes distinctly stratified (Palacios, 2004), with high temperatures on the surface (above $26^{\circ} \mathrm{C}$ ), causing the thermocline to descend and so does hammerheads preferred habitat (Ketchum et al., 2014). Our isotopic analysis reveals low 
seasonal differences coupled with annual fluctuations depending on ENSO cycles for hammerheads in the GMR. Previous studies have shown horizontal and vertical migrations models of hammerheads around the TEP oceanic islands using acoustic and satellite telemetry to showcase two types of migratory movements: one restricted to inshore habitats and one dispersive to offshore habitats near the islands (Hearn et al., 2010; Bessudo et al., 2011; Ketchum et al., 2014). Isotopic signatures from our study showed that in years with warmer conditions hammerheads might engage in offshore foraging strategies, possible feeding outside of the GMR boundaries, thus, becoming vulnerable to fishing pressures as international fleets expand toward the GMR (Bonaccorso et al., 2021).

\section{CONCLUSION}

Our data suggest that hammerheads sharks broaden their isotopic niche when environmental fluctuations occur in their preferred environment, probably as natural behavior or physiological response to climate adaptation. Predominantly, sharks have broad thermal tolerance and a great potential for environmental adaptation, as they have demonstrated through millennia, withstanding natural climate variability (Tricas and Sisneros, 2004; Dulvy and Forrest, 2010). Our study supports this statement by showing that hammerhead sharks feeding strategies adapt to the climate variability occurring during El Niño and La Niña events within the GMR. Yet, as climate change and extreme weather events become magnified and more frequent, the future of hammerhead shark populations remains uncertain unless incorporate climate-related conservation strategies into the management of this species.

\section{DATA AVAILABILITY STATEMENT}

The raw data supporting the conclusions of this article will be made available by the authors, without undue reservation.

\section{REFERENCES}

Acuña-Marrero, D., Jiménez, J., Smith, F., Doherty, Jr., and Pf Hearn, A. (2014). Whale shark (Rhincodon typus) seasonal presence, residence time and habitat use at Darwin Island, Galapagos Marine Reserve. PLoS One 9:12. doi: 10.1371/ journal.pone.0115946

Acuña-Marrero, D., Smith, A. N., Salinas-de-León, P., Harvey, E. S., Pawley, M. D., and Anderson, M. J. (2018). Spatial patterns of distribution and relative abundance of coastal shark species in the Galapagos Marine Reserve. Mar. Ecol. Prog. Ser. 593, 73-95. doi: 10.3354/meps12505

Adams, G. D., Flores, D., Flores, O. G., Aarestrup, K., and Svendsen, J. C. (2016). Spatial ecology of blue shark and shortfin mako in southern Peru: local abundance, habitat preferences and implications for conservation. Endanger. Species Res. 31, 19-32. doi: 10.3354/esr00744

Awkerman, J. A., Hobson, K. A., and Anderson, D. J. (2007). Isotopic ( $\delta 15 \mathrm{~N}$ and $813 \mathrm{C}$ ) evidence for intersexual foraging differences and temporal variation in habitat use in waved albatrosses. Can J. Zool. 85, 273-279. doi: 10.1139/ z06-202

\section{ETHICS STATEMENT}

The animal study was reviewed and approved by Galapagos National Park Directorate.

\section{AUTHOR CONTRIBUTIONS}

PS-D-L and DP-R conceived the study and designed the methodology. CA-U, PS-D-L, ER-L, LV-P, JS-M, and DP-R performed the field and laboratory work. CA-U, PS-D-L, and DP-R contributed to funding acquisition and wrote the original draft. DP-R conducted data analyses. ER-L, LV-P, and JS-M reviewed early manuscript versions. All authors gave final approval of the version to be published and agreed to be accountable for all aspects of the work.

\section{FUNDING}

Project funding and support was provided by the Helmsley Charitable Trust, the Gordon and Betty Moore Foundation, The Rufford Foundation, The Save Our Seas Foundation, Focused on Nature, Ocean 52, Dario Mariani, Miguel Bosé, and Mark Qi Wong.

\section{ACKNOWLEDGMENTS}

We are grateful to the Charles Darwin Foundation, Universidad San Francisco de Quito, and Galapagos National Park Directorate for the institutional support. We would like to thank the E/V Queen Mabel crew, the P/V Sierra Negra and Ecuadorian Navy $\mathrm{R} / \mathrm{V}$ Sirius for their fieldwork support, as well as the rangers and CDF volunteers that assisted with this study, especially to Renata Leemhuis. We would also like to the GSC, ESPOL, and Luis Dominguez' team for providing the facilities for sample processing. This publication is contribution number 2431 of the Charles Darwin Foundation for the Galapagos Islands.

Banks, S., Vera, M., and Chiriboga, A. (2009). Establishing reference points to assess long-term change in zooxanthellate coral communities of the northern Galápagos coral reefs. Gal. Res. 66, 43-64.

Baque-Menoscal, J., Paez-Rosas, D., and Wolff, M. (2012). Feeding habits of two pelagic fish Thunnus albacares and Acanthocybium solandri from the Galapagos Marine Reserve. Rev. Biol. Mar. Oceanogr. 47, 1-11.

Barber, R. T., and Chávez, F. P. (1986). Ocean variability in relation to living resources during the 1982-83 El Niño. Nature 319, 279-285.

Barber, R. T., Sanderson, M. P., Lindley, S. T., Chai, F., Newton, J., Trees, C. C., et al. (1996). Primary productivity and its regulation in the equatorial Pacific during and following the 1991-1992 El Nino. Deep Sea Res. Part II: Top Stu. Oceanogr. 43, 933-969. doi: 10.1016/0967-0645(96)00035-5

Barnett, T. P., Pierce, D. W., AchutaRao, K. M., Gleckler, P. J., Santer, B. D., Gregory, J. M., et al. (2005). Penetration of human-induced warming into the world's oceans. Sci 309, 284-287. doi: 10.1126/science.1112418

Baum, J. K., and Worm, B. (2009). Cascading top-down effects of changing oceanic predator abundances. J. Anim. Ecol. 78, 699-714. doi: 10.1111/j.1365-2656. 2009.01531.x 
Behrenfeld, M. J., O’Malley, R. T., Siegel, D. A., McClain, C. R., Sarmiento, J. L., Feldman, G. C., et al. (2006). Climate-driven trends in contemporary ocean productivity. Nat 444, 752-755. doi: 10.1038/nature05317

Behrenfeld, M. J., Randerson, J. T., McClain, C. R., Feldman, G. C., Los, S. O., Tucker, C. J., et al. (2001). Biospheric primary production during an ENSO transition. Sci 291, 2594-2597. doi: 10.1126/science.1055071

Benson, S. R., Croll, D. A., Marinovic, B. B., Chavez, F. P., and Harvey, J. T. (2002). Changes in the cetacean assemblage of a coastal upwelling ecosystem during El Niño 1997-98 and La Niña 1999. Prog. Oceanogr. 54, 279-291.

Bessudo, S., Soler, G. A., Klimley, A. P., Ketchum, J. T., Hearn, A., and Arauz, R. (2011). Residency of the scalloped hammerhead shark (Sphyrna lewini) at Malpelo Island and evidence of migration to other islands in the Eastern Tropical Pacific. Enviro Biol. Fishes 91, 165-176.

Bonaccorso, E., Ordóñez-Garza, N., Pazmiño, D. A., Hearn, A., Páez-Rosas, D., Cruz, S., et al. (2021). International fisheries threaten globally endangered sharks in the Eastern Tropical Pacific Ocean: the case of the Fu Yuan Yu Leng 999 reefer vessel seized within the Galápagos Marine Reserve. Sci. Rep. 11, 1-11. doi: 10.1038/s41598-021-94126-3

Cai, W., Borlace, S., Lengaigne, M., Van Rensch, P., Collins, M., Vecchi, G., et al. (2014). Increasing frequency of extreme El Niño events due to greenhouse warming. Nat. Clim. Change 4, 111-116.

Carlisle, A. B., Kim, S. L., Semmens, B. X., Madigan, D. J., Jorgensen, S. J., Perle, C. R., et al. (2012). Using stable isotope analysis to understand the migration and trophic ecology of northeastern Pacific white sharks (Carcharodon carcharias). PLoS One 7:2. doi: 10.1371/journal.pone.0030492

Casini, M., Hjelm, J., Molinero, J. C., Lövgren, J., Cardinale, M., Bartolino, V., et al. (2009). Trophic cascades promote threshold-like shifts in pelagic marine ecosystems. Proc. Natl. Acad. Sci. 106, 197-202. doi: 10.1073/pnas.080664 9105

Chavez, F. P., Ryan, J., Lluch-Cota, S. E., and Ñiquen, M. (2003). From anchovies to sardines and back: multidecadal change in the Pacific Ocean. Sci 299, 217-221. doi: $10.1126 /$ science. 1075880

Chen, W. Y., and Dool, H. M. V. D. (1999). Significant change of extratropical natural variability and potential predictability associated with the El Nino/Southern Oscillation. Tellus A 51, 790-802. doi: 10.1034/j.1600-0870. 1999.00017.x

Cheung, W. W., Lam, V. W., Sarmiento, J. L., Kearney, K., Watson, R. E. G., Zeller, D., et al. (2010). Large-scale redistribution of maximum fisheries catch potential in the global ocean under climate change. Glob. Change Biol. 16, 24-35. doi: 10.1111/j.1365-2486.2009.01995.x

Collins, M., An, S. I., Cai, W., Ganachaud, A., Guilyardi, E., Jin, F. F., et al. (2010). The impact of global warming on the tropical Pacific Ocean and El Niño. Nat. Geo 3, 391-397.

Doney, S. C., Ruckelshaus, M., Duffy, J. E., Barry, J. P., Chan, F., English, C. A., et al. (2011). Climate change impacts on marine ecosystems. Ann. Rev. Mar. Sci. 4, 11-37.

Dulvy, N. K., Baum, J. K., Clarke, S., Compagno, L. J., Cortés, E., Domingo, A., et al. (2008). You can swim but you can't hide: the global status and conservation of oceanic pelagic sharks and rays. Aquat. Conser. 18, 459-482.

Dulvy, N. K., and Forrest, R. E. (2010). Life Histories, Population Dynamics, and Extinction Risks in Chondrichthyans. In Sharks and Their Relatives II. Boca Raton, FL: CRC Press, 655-696.

Edgar, G. J., Banks, S., Fariña, J. M., Calvopiña, M., and Martínez, C. (2004). Regional biogeography of shallow reef fish and macro-invertebrate communities in the Galapagos archipelago. J. Biogeogr. 31, 1107-1124. doi: 10.1111/j.1365-2699.2004.01055.x

Edgar, G. J., Banks, S. A., Brandt, M., Bustamante, R. H., Chiriboga, A., Earle, S. A., et al. (2010). El Niño, grazers and fisheries interact to greatly elevate extinction risk for Galapagos marine species. Glob. Change Biol. 16, 2876-2890.

Estes, J. A., Terborgh, J., Brashares, J. S., Power, M. E., Berger, J., Bond, W. J., et al. (2011). Trophic downgrading of planet Earth. Sci 333, 301-306. doi: 10.1126/science. 1205106

Ferretti, F., Curnick, D., Liu, K., Romanov, E. V., and Block, B. A. (2018). Shark baselines and the conservation role of remote coral reef ecosystems. Sci. Adv. 4:3. doi: 10.1126/sciadv.aaq0333

Ferretti, F., Worm, B., Britten, G. L., Heithaus, M. R., and Lotze, H. K. (2010). Patterns and ecosystem consequences of shark declines in the ocean. Ecol. Lett. 13, 1055-1071. doi: 10.1111/j.1461-0248.2010.01489.x
Galván-Magaña, F., Polo-Silva, C., Hernández-Aguilar, S. B., SandovalLondoño, A., Ochoa-Díaz, M. R., Aguilar-Castro, N., et al. (2013). Shark predation on cephalopods in the Mexican and Ecuadorian Pacific Ocean. Deep Sea Res. Part II Top. Stud. Oceanogr. 95, 52-62. doi: 10.1016/j.dsr2.2013.04.002

Griffiths, S. P., Young, J. W., Lansdell, M. J., Campbell, R. A., Hampton, J., Hoyle, S. D., et al. (2010). Ecological effects of longline fishing and climate change on the pelagic ecosystem off eastern Australia. Rev. Fish Biol. Fish 20, 239-272.

Harpp, K., and Geist, D. (2002). Wolf-Darwin lineament and plume-ridge interaction in northern Galápagos. Geochem. Geophy. 3, 1-19.

Hearn, A., Ketchum, J., Klimley, A. P., Espinoza, E., and Penaherrera, C. (2010). Hotspots within hotspots? hammerhead shark movements around Wolf island, Galapagos Marine Reserve. Mar. Biol. 157, 1899-1915. doi: 10.1007/s00227010-1460-2

Heithaus, M. R., Frid, A., Wirsing, A. J., and Worm, B. (2008). Predicting ecological consequences of marine top predator declines. Trends Ecol. Evol. 23, 202-210. doi: 10.1016/j.tree.2008.01.003

Heupel, M. R., Knip, D. M., Simpfendorfer, C. A., and Dulvy, N. K. (2014). Sizing up the ecological role of sharks as predators. Mar. Ecol. Progs Ser. 495, 291-298.

Hobson, K. A., Ambrose, W. G. Jr., and Renaud, P. E. (1995). Sources of primary production, benthic-pelagic coupling, and trophic relationships within the Northeast Water Polynya: insights from $\delta 13 \mathrm{C}$ and $\delta 15 \mathrm{~N}$ analysis. Mar. Ecol. Prog. Series 128, 1-10. doi: 10.3354/meps128001

Hoegh-Guldberg, O., and Bruno, J. F. (2010). The impact of climate change on the world's marine ecosystems. Sci 328, 1523-1528. doi: 10.1126/science.1189930

Hoffmayer, E. R., Frank, J. S., Driggers, W. B., and Howey, P. W. (2013). Diel vertical movements of a scalloped hammerhead, Sphyrna lewini, in the northern Gulf of Mexico. Bull Mar. Sci. 89, 551-557.

Jackson, A. L., Inger, R., Parnell, A. C., and Bearhop, S. (2011). Comparing isotopic niche widths among and within communities: Bayesian analysis of stable isotope data. J. Anim. Ecol. 80, 595-602. doi: 10.1111/j.1365-2656.2011.01806.x

Jimenez-Uzcategui, G., Vaca, L., Cotin, J., Garcia, C., Costales, A., Sevilla, C., et al. (2019). Using referential values of $\delta 13 \mathrm{C}$ and $\delta 15 \mathrm{~N}$ to infer the foraging ecology of Galápagos seabirds. Mar. Ornithol. 5-10.

Jorgensen, S. J., Klimley, A. P., and Muhlia-Melo, A. (2009). Diving of scalloped hammerhead in anoxic zone in Gulf of California. J. Fish Biol. 74, 1682-1687. doi: 10.1111/j.1095-8649.2009.02230.x

Ketchum, J. T., Hearn, A., Klimley, A. P., Espinoza, E., Peñaherrera, C., and Largier, J. L. (2014). Seasonal changes in movements and habitat preferences of the scalloped hammerhead shark (Sphyrna lewini) while refuging near an oceanic island. Mar. Biol. 161, 755-767. doi: 10.1007/s00227-013-2375-5

Kim, S. L., and Koch, P. L. (2012). Methods to collect, preserve, and prepare elasmobranch tissues for stable isotope analysis. Environ. Biol. Fishes 95, 53-63. doi: 10.1007/s10641-011-9860-9

Klimley, A. P. (1987). The determinants of sexual segregation in the scalloped hammerhead, Sphyrna lewini. Environ. Biol. Fishes 18, 27-40.

Klimley, A. P. (1993). Highly directional swimming by scalloped hammerhead sharks, Sphyrna lewini, and subsurface irradiance, temperature, bathymetry, and geomagnetic field. Mar. Biol. 117, 1-22. doi: 10.1007/bf00346421

Klimley, A. P., and Brown, S. T. (1983). Stereophotography for the field biologist: measurement of lengths and three-dimensional positions of free-swimming sharks. Mar. Biol. 74, 175-185. doi: 10.1007/bf00413921

Lamb, R. W., Smith, F., Aued, A. W., Salinas-de-León, P., Suarez, J., GomezChiarri, M., et al. (2018). El Niño drives a widespread ulcerative skin disease outbreak in Galapagos marine fishes. Sci. Rep. 8, 1-11.

Lehodey, P., Bertignac, M., Hampton, J., Lewis, A., and Picaut, J. (1997). El Niño Southern Oscillation and tuna in the western Pacific. Nature 389, 715-718.

Li, Y., Zhang, Y., Hussey, N. E., and Dai, X. (2016). Urea and lipid extraction treatment effects on $\delta 15 \mathrm{~N}$ and $\delta 13 \mathrm{C}$ values in pelagic sharks. Rapid Comm. Mass Spectrom. 30, 1-8. doi: 10.1002/rcm.7396

Logan, J. M., Jardine, T. D., Miller, T. J., Bunn, S. E., Cunjak, R. A., and Lutcavage, M. E. (2008). Lipid corrections in carbon and nitrogen stable isotope analyses: comparison of chemical extraction and modelling methods. J. Anim. Ecol. 77, 838-846. doi: 10.1111/j.1365-2656.2008.01394.x

MacNeil, M. A., Skomal, G. B., and Fisk, A. T. (2005). Stable isotopes from multiple tissues reveal diet switching in sharks. Mar. Ecol. Progr. Series 302, 199-206. doi: 10.3354/meps302199

Martínez-Ortiz, J., Aires-da-Silva, A. M., Lennert-Cody, C. E., and Maunder, M. N. (2015). The Ecuadorian artisanal fishery for large pelagics: species composition 
and spatio-temporal dynamics. PLoS One 2015:10. doi: 10.1371/journal.pone. 0135136

Matich, P., and Heithaus, M. R. (2012). Effects of an extreme temperature event on the behavior and age structure of an estuarine top predator, Carcharhinus leucas. Mar. Ecol. Prog. Ser. 447, 165-178. doi: 10.3354/meps09497

Munroe, S. E. M., Simpfendorfer, C. A., and Heupel, M. R. (2014). Defining shark ecological specialisation: concepts, context, and examples. Rev. Fish Biol. Fisher 24, 317-331. doi: 10.1007/s11160-013-9333-7

Myers, R. A., Baum, J. K., Shepherd, T. D., Powers, S. P., and Peterson, C. H. (2007). Cascading effects of the loss of apex predatory sharks from a coastal ocean. Sci 315, 1846-1850. doi: 10.1126/science.1138657

Nalesso, E., Hearn, A., Sosa-Nishizaki, O., Steiner, T., Antoniou, A., Reid, A., et al. (2019). Movements of scalloped hammerhead sharks (Sphyrna lewini) at Cocos Island, Costa Rica and between oceanic islands in the Eastern Tropical Pacific. PLoS One 14:e0213741. doi: 10.1371/journal.pone.0213741

Nims, B. D., Vargas, F. H., Merkel, J., and Parker, P. G. (2008). Low genetic diversity and lack of population structure in the endangered Galápagos penguin (Spheniscus mendiculus). Conserv. Genet. 9, 1413-1420.

Ñiquen, M., and Bouchon, M. (2004). Impact of El Niño events on pelagic fisheries in Peruvian waters. Deep Sea Res. 51, 563-574.

Pachauri, R. K., and Reisinger, A. (2008). Climate change 2007. Synthesis Report. Contribution of Working Groups I, II and III to the Fourth Assessment Report. Cambridge: Cambridge University Press.

Pacoureau, N., Rigby, C. L., Kyne, P. M., Sherley, R. B., Winker, H., Carlson, J. K., et al. (2021). Half a century of global decline in oceanic sharks and rays. Nature 589, 567-571. doi: 10.1038/s41586-020-03173-9

Páez-Rosas, D., Aurioles-Gamboa, D., Alava, J. J., and Palacios, D. M. (2012). Stable isotopes indicate differing foraging strategies in two sympatric otariids of the Galapagos Islands. J. Exp. Mar. Biol. Ecol. 424, 44-52.

Páez-Rosas, D., Riofrío-Lazo, M., Ortega, J., de Dios Morales, J., Carvajal, R., and Alava, J. J. (2018a). Southern elephant seal vagrants in Ecuador: a symptom of La Niña events? Mar. Biodivers. Rec. 11:13.

Páez-Rosas, D., Insuasti-Zarate, P., Riofrío-Lazo, M., and Galván-Magaña, F. (2018b). Feeding behavior and trophic interaction of three shark species in the Galapagos Marine Reserve. PeerJ 6:e4818. doi: 10.7717/peerj.4818

Páez-Rosas, D., Galván-Magaña, F., Baque-Menoscal, J., Tripp-Valdez, A., Fischer, C., and Hearn, A. (2020a). Trophic preferences of three pelagic fish inhabiting the Galapagos Marine Reserve: ecological inferences using multiple analyses. Enviro Biol. Fishes 103, 647-665. doi: 10.1007/s10641-020-00967-8

Páez-Rosas, D., Moreno-Sánchez, X., Tripp-Valdez, A., Elorriaga-Verplancken, F. R., and Carranco-Narváez, S. (2020b). Changes in the Galapagos sea lion diet as a response to El Niño-Southern Oscillation. Reg. Stud. Mar. Sci. 2020:101485.

Páez-Rosas, D., Torres, J., Espinoza, E., Marchetti, A., Seim, H., and Riofrío-Lazo, M. (2021). Declines and recovery in endangered Galapagos pinnipeds during the El Niño event. Sci. Rep. 11, 1-15. doi: 10.1038/s41598-021-88350-0

Paez-Rosas, D., Villegas-Amtmann, S., and Costa, D. (2017). Intraspecific variation in feeding strategies of Galapagos sea lions: A case of trophic specialization. PLoS One 2017:12. doi: 10.1371/journal.pone.0185165

Palacios, D. M. (2004). Seasonal patterns of sea-surface temperature and ocean color around the Galápagos: regional and local influences. Deep Sea Res. 51, 43-57.

Peñaherrera-Palma, C., van Putten, I., Karpievitch, Y. V., Frusher, S., LlerenaMartillo, Y., Hearn, A. R., et al. (2018). Evaluating abundance trends of iconic species using local ecological knowledge. Biol. Conser. 225, 197-207.

Penalba, O. C., and Rivera, J. A. (2016). Precipitation response to El Niño/La Niña events in Southern South America-emphasis in regional drought occurrences. Adv. Geosci. 2016:42.

Pistevos, J. C., Nagelkerken, I., Rossi, T., Olmos, M., and Connell, S. D. (2015). Ocean acidification and global warming impair shark hunting behaviour and growth. Sci. Rep. 5, 1-10. doi: 10.1038/srep16293

Post, D. M., Layman, C. A., Arrington, D. A., Takimoto, G., Quattrochi, J., and Montana, C. G. (2007). Getting to the fat of the matter: models, methods and assumptions for dealing with lipids in stable isotope analyses. Oecologia 152, 179-189. doi: 10.1007/s00442-006-0630-x

Preti, A., Soykan, C. U., Dewar, H., Wells, R. D., Spear, N., and Kohin, S. (2012). Comparative feeding ecology of shortfin mako, blue and thresher sharks in the California Current. Environ. Biol. Fish. 95, 127-146.
Preti, A. N., Smith, S. E., and Ramon, D. A. (2004). Diet differences in the thresher shark (Alopias vulpinus) during transition from a warm-water regime to a cool-water regime off California-Oregon, 1998-2000. Cal. Coop. Ocean Fish. 45:118.

Richert, J. E., Galvan, A. P., and Klimley. (2015). The use of nitrogen stable isotopes in the study of migratory fishes and pelagic marine ecosystems in the Eastern Tropical Pacific Ocean. Mar. Biol. 162, 1099-1110.

Riofrío-Lazo, M., Arreguín-Sánchez, F., and Páez-Rosas, D. (2017). Population abundance of the endangered Galapagos sea lion Zalophus wollebaeki in the southeastern Galapagos archipelago. PLoS One 2017:12. doi: 10.1371/journal. pone.0168829

Robinson, R. A., Crick, H. Q., Learmonth, J. A., Maclean, I. M., Thomas, C. D., Bairlein, F., et al. (2009). Travelling through a warming world: climate change and migratory species. Endanger. Species Res. 7, 87-99. doi: 10.3354/esr00095

Robles, Y. A., Montes, L. A., and Vega, Á. J. (2015). Caracterización de la captura de tiburones por la pesca artesanal en los manglares de David, Golfo de Chiriquí, Pacífico de Panamá. Tecnociencias 17, 11-30.

Rojas, Y. E. T., Osuna, F. P., Herrera, A. H., Magaña, F. G., García, S. A., Ortíz, H. V., et al. (2014). Feeding grounds of juvenile scalloped hammerhead sharks (Sphyrna lewini) in the south-eastern Gulf of California. Hydrobiologia 726, 81-94. doi: 10.1007/s10750-013-1753-9

Rosa, R., and Seibel, B. A. (2008). Synergistic effects of climate-related variables suggest future physiological impairment in a top oceanic predator. Proc. Natl. Acad. Sci. 105, 20776-20780. doi: 10.1073/pnas.0806886105

Ruiz, D. J., Banks, S., and Wolff, M. (2016). Elucidating fishing effects in a largepredator dominated system: the case of Darwin and Wolf Islands (Galápagos). J. Sea Res. 107, 1-11. doi: 10.1016/j.seares.2015.11.001

Salinas-de-León, P., Acuña-Marrero, D., Rastoin, E., Friedlander, A. M., Donovan, M. K., and Sala, E. (2016). Largest global shark biomass found in the northern Galápagos Islands of Darwin and Wolf. PeerJ 4:e1911. doi: 10.7717/peerj.1911

Salinas-de-León, P., Andrade, S., Arnés-Urgellés, C., Bermudez, J. R., Bucaram, S., Buglass, S., et al. (2020). Evolution of the Galapagos in the Anthropocene. Nat. Clim. Change 2020, 1-3. doi: 10.1002/ece3.6020

Salinas-de-León, P., Fierro-Arcos, D., Suarez-Moncada, J., Proaño, A., GuachisacaSalinas, J., and Páez-Rosas, D. (2019). A matter of taste: Spatial and ontogenetic variations on the trophic ecology of the tiger shark at the Galapagos Marine Reserve. PLoS One 14:9. doi: 10.1371/journal.pone.0222754

Salinas-de-León, P., Hoyos-Padilla, E. M., and Pochet, F. (2017). First observation on the mating behaviour of the endangered scalloped hammerhead shark Sphyrna lewini in the Tropical Eastern Pacific. Enviro Biol. Fishes 100, 16031608. doi: 10.1007/s10641-017-0668-0

Santana-Piñeros, A. M., Cruz-Quintana, Y., May-Tec, A. L., Mera-Loor, G., Aguirre-Macedo, M. L., Suárez-Morales, E., et al. (2020). The 2015-2016 El Niño increased infection parameters of copepods on Eastern Tropical Pacific dolphinfish populations. PLoS One 15:e232737.

Schwarz, J. F., Mews, S., DeRango, E. J., Langrock, R., Piedrahita, P., Páez-Rosas, D., et al. (2021). Individuality counts: A new comprehensive approach to foraging strategies of a tropical marine predator. Oecologia 195, 313-325. doi: 10.1007/ s00442-021-04850-w

Shiffman, D. S., Kaufman, L., Heithaus, M., and Hammerschlag, N. (2019). Intraspecific differences in relative isotopic niche area and overlap of cooccurring sharks. Aquat. Ecol. 53, 233-250. doi: 10.1007/s10452-019-09 685-5

Stevens, J. D., Bonfil, R., Dulvy, N. K., and Walker, P. A. (2000). The effects of fishing on sharks, rays, and chimaeras (chondrichthyans), and the implications for marine ecosystems. ICES J. Mar. Sci. 57, 476-494. doi: 10.1006/jmsc.2000. 0724

Sydeman, W. J., Poloczanska, E., Reed, T. E., and Thompson, S. A. (2015). Climate change and marine vertebrates. Sci 350, 772-777. doi: 10.1126/science.aac9874

Sydeman, W. J., Thompson, S. A., and Kitaysky, A. (2012). Seabirds and climate change: roadmap for the future. Mar. Ecol. Prog. Ser. 454, 107-117. doi: 10.3354/ meps09806

Tamburin, E., Kim, S. L., Elorriaga-Verplancken, F. R., Madigan, D. J., HoyosPadilla, M., Sánchez-González, A., et al. (2019). Isotopic niche and resource sharing among young sharks (Carcharodon carcharias and Isurus oxyrinchus) in Baja California, Mexico. Mar. Ecol. Prog. Ser. 613, 107-124. doi: 10.3354/ meps12884 
Torres-Rojas, Y., Hernandez-Herrera, A., and Galvan-Magana, F. (2006). Feeding habits of the scalloped hammerhead shark, Sphyrna lewini, in Mazatlán waters, southern Gulf of California, Mexico. Cybium 30, 85-90.

Torres-Rojas, Y. E., Páez Osuna, F., Camalich, J., and Galván Magaña, F. (2015). Diet and trophic level of scalloped hammerhead shark (Sphyrna lewini) from the Gulf of California and Gulf of Tehuantepec. Mexico. Iran J. Fish Sci. 14, $767-785$.

Tricas, T. C., and Sisneros, J. A. (2004). Ecological Functions and Adaptations of The Elasmobranch Electrosense. In The Senses of Fish. Dordrecht: Springer, 308-329.

Trueman, C. N., and Glew, K. S. J. (2019). Isotopic Tracking of Marine Animal Movement. In Tracking Animal Migration with Stable Isotopes. Cambridge, MA: Academic Press, 137-172.

Valle, C. A., Cruz, F., Cruz, J. B., Merlen, G., and Coulter, M. C. (1987). The impact of the 1982-1983 El Niño-Southern Oscillation on seabirds in the Galapagos Islands, Ecuador. J. Geophys. Res. Oceans 92, 14437-14444.

Victor, B. C., Wellington, G. M., Robertson, D. R., and Ruttenberg, B. I. (2001). The effect of the El Niño-Southern Oscillation event on the distribution of reef-associated labrid fishes in the eastern Pacific Ocean. Bull Mar. Sci. 69, 279-288.

Walthers, G. R., Post, E., Convey, P., Menzel, A., Parmesan, C., Beebee, T. J., et al. (2002). Ecological responses to recent climate change. Nature 416, 389-395.

Wang, C., and Fiedler, P. C. (2006). ENSO variability and the eastern tropical Pacific: a review. Prog. Oceanogr. 69, 239-266. doi: 10.1073/pnas.94.16.8354

Wang, G., Cai, W., Gan, B., Wu, L., Santoso, A., Lin, X., et al. (2017). Continued increase of extreme El Niño frequency long after $1.5 \mathrm{C}$ warming stabilization. Nat. Clim. Change 7, 568-572.

Wellington, G. M., Glynn, P. W., Strong, A. E., Navarrete, S. A., Wieters, E., and Hubbard, D. (2001). Crisis on coral reefs linked to climate change. EOS 82, 1-5. doi: $10.1038 /$ srep08402

Wernberg, T., Smale, D. A., Tuya, F., Thomsen, M. S., Langlois, T. J., De Bettignies, T., et al. (2013). An extreme climatic event alters marine ecosystem structure in a global biodiversity hotspot. Nat. Clim. Change 3, 78-82.
White, E. R., Myers, M. C., Flemming, J. M., and Baum, J. K. (2015). Shifting elasmobranch community assemblage at Cocos Island-an isolated marine protected area. Conserv. Biol. 29, 1186-1197. doi: 10.1111/cobi. 12478

Whitehead, H., Papastavrou, V., and Smith, S. C. (1989). Feeding success of sperm whales and sea-surface temperature off the Galapagos Islands. Mar. Ecol. Prog. Ser. 1989, 201-203. doi: 10.3354/meps05 3201

Wikelski, M., and Thom, C. (2000). Marine iguanas shrink to survive El Niño. Nature 403, 37-38. doi: 10.1038/47396

Zanella, I., López-Garro, A., and Cure, K. (2019). Golfo Dulce: critical habitat and nursery area for juvenile scalloped hammerhead sharks Sphyrna lewini in the Eastern Tropical Pacific Seascape. Envir. Biol. Fish. 102, 1291-1300. doi: 10.1007/s10641-019-00907-1

Conflict of Interest: The authors declare that the research was conducted in the absence of any commercial or financial relationships that could be construed as a potential conflict of interest.

Publisher's Note: All claims expressed in this article are solely those of the authors and do not necessarily represent those of their affiliated organizations, or those of the publisher, the editors and the reviewers. Any product that may be evaluated in this article, or claim that may be made by its manufacturer, is not guaranteed or endorsed by the publisher.

Copyright (c) 2021 Arnés-Urgellés, Salinas-de-León, Rastoin-Laplane, Vaca-Pita, Suárez-Moncada and Páez-Rosas. This is an open-access article distributed under the terms of the Creative Commons Attribution License (CC BY). The use, distribution or reproduction in other forums is permitted, provided the original author(s) and the copyright owner(s) are credited and that the original publication in this journal is cited, in accordance with accepted academic practice. No use, distribution or reproduction is permitted which does not comply with these terms. 